\title{
有限要素法による貯水池斜面の地すべりを起因とする造波解析 Analysis of Water Waves due to Landslide at the Reservoir Slope by Finite Element Method
}

\author{
吉松弘行*) \\ Hiroyuki YOSHIMATSU
}

\begin{abstract}
There are reported many serious disasters associated with water waves due to landslides suddenly inflowing into a reservoir and a bay. The estimation of water waves property has been carried out through the calculation of finite defferential method. This paper discusses the numerical procedure of finite element method to predict the water waves generated by landslides, and presents the numerical procedure simply combined with the balancing tensor diffusivity term into the finite element method in order to stabilize the numerical calculation. The results of the previous model experiments are compared with the properiety of the present method.

Key words : water wave, landslide, F. E. M., numerical analysis

和文要旨

地すべり地塊の眝水池への突入を起因する造波は大規模の災害を引き起こすことが報告されている.この造波を予測するため有 限要素法による数值解析手法を検討した。数値計算の安定化のためBTD項を簡単に計算する手法を提案するとともに, 既往の模型 実験結果との比較を通して提案手法の妥当性を述べた。

キーワード : 造波, 地すべり, 有限要素法, 数值解析
\end{abstract}

\section{1.まえがき}

地すべりなどを起因とする移動地塊が貯水池や湾内に 急激に突入することによって，貯水池や湾内の水位が大 きく変動する造波現象はこれまで津波として多数報告さ

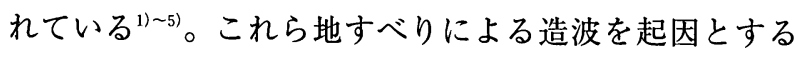
災害の中で特に大規模ものは, 1963年10月 9 日, イタリ アのバイオントダムの䝪水池斜面のトック山に発生した 移動地塊が $2.4 \times 10^{8} \mathrm{~m}^{3}$ 規模の岩盤すべりを起因とするも のである(6) 8)。この災害は突然 $2 \times 1.6 \mathrm{~km}^{2}$ の面積にわた り速度 $25 \sim 30 \mathrm{~m} / \mathrm{sec}$ と推定される大規模な岩盤すべり によって, 湖水総面積の約半分に及ぶ貯水池が移動地塊 によって埋塞され, ダム右岸の地点で $90 \mathrm{~m}$, 左岸部では $130 \mathrm{~m}$ の波高でダム本体を越水する大規模な造波現象が 生じ, ダム地点から $1.8 \mathrm{~km}$ の下流に位置するロンガロー ネ村を約 $7 \mathrm{~m}$ 達する波高の段波が襲い, 約 2,600 名も の死者を出したものである。

䝪水池内での造波現象ではないが，1958年 7 月 9 日， アラスカ州の東南, カナダ領に接する長さ $11.3 \mathrm{~km}$, 最 大幅3. $2 \mathrm{~km}$ ほどのフィヨルドのリッヤ湾で, マグニ チュード7.9の地震を起因として巨大な岩首崩落が発生 した ${ }^{9) 100}$ 。これによって引き起こされた津波は湾内の直 線部では $64 \mathrm{~m}$ 以上の波高に達し, 滑落地点の対岸では 525 $\mathrm{m}$, 落下地点の側岸でも $180 \mathrm{~m}$ も陸部へと遡上している。

同様な造波現象による災害として, 我が国に扔いても 1792年 5 月 21 日頃強い地震が九州島原半島の中央部で発 生し, 標高約 $700 \mathrm{~m}$ の眉山に $5 \times 10^{8} \mathrm{~m}^{3}$ と推定される大規 模な山体崩壊が発生し, 多量の岩屑が島原の街を流下破

*) 砂防・地すべり技術センター

テ102-0074 東京都千代田区九段南4-8-21 山脇ビル
壊し, 有明湾へ突入した 22 。この大規模崩壊の移動地塊

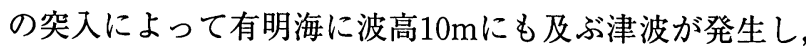
島原半島の有明湾沿岸のほほ全域とこれに対置する熊本 県の玉名, 宇土, 天草に大災害をもたらし，15,155名の 死者，8，478戸の家屋流出の被害をもたらしている。

このように，地すべりなどの滑落地塊を起因とする造 波は局所的に著しい高い波高及び斜面への遡上現象を有 し, 滑落地塊が $10^{6} \mathrm{~m}^{3}$ 以上になると極端な大規模の災害 をもたらしている。

我が国は火山列島として脆弱な地質, 急峻な地形条件 を有しており, 台風などの気象要因を起因として, 地す ベりなどが多発している現状である。地すべりなどに よって生成された地塊が貯水池や湾内に突入して大規模 な造波現象を引き起こす潜在的な危険性が我が国におい ては恒に存在していると言える。

バイオントダムの災害やロックフィルダムの建設の増 加などと相まって地すべり地塊の貯水池への突入による 造波現象の予測に関する研究が精力的に行われるように なった。初期の段階では, 造波現象が貯水池内に突入す る地塊の速度, 規模の影響を強く受けるため解析的研究 も行われていたが㤱,12)，主に水理模型実験を通して検討 がなされていた ${ }^{13)}$ 。しかながら，これら実験において 造波の遡上域まで検討することとなると大規模の実験施 設とならざるを得ず，近年の高速，大容量の電子計算機 の出現と有限差分法や有限要素法の離散化技術の向上に よって経済性の有意な数值解析手法の検討が進められる ようになった。

この数值解析手法において使用される基礎方程式は, 過去の災害事例から長波現象による水位変動に起因する 
として鉛直方向に平均流速を仮定する浅水長波式が用い られる ${ }^{14)}$ 。この基礎方程式は移流項と拡散項を含むため, 解の振動を防ぐため風上差分を用いた有限差分法による 解析が一般的であり, 解析領域は矩形の格子，すなわち，

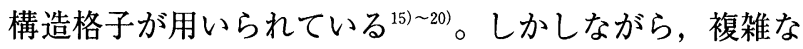
地形形状をなす䝪水池の場合には，局所地形の影響によ る水位の增幅現象を解析するため非常に細かな格子設定 を必要とし，解析のための節点数が増加する。さらに境 界領域では仮想格子点を設定しなければならないため, 地すべり地塊の貯水池への突入に関する境界条件の設定 が困難を伴うなど, 解析が複雑になるとともに多量の解 析時間や大容量, 高速の計算機が必要である。

一方，任意形状の解析領域を対象とする非構造格子に よる有限要素法を用いた解析事例は比較的少なく ${ }^{21)}$, 地 すべり地塊の䝪水池への突入を考慮した三次元的な解析 手法は開発されていない。有限要素法によるこの種の解 析がこれまで実施されなかったのは以下の理由によるも のと考えられる。

1) 中央差分によるパブノフ・ガラーキン型有限要素法 では数值的な不安定性が生じ, 風上化などの安定化 の処理が必要であること。

2 ）傾斜面を流水が遡上する場合, 流水とそれが存在し ない境いは移動境界であり，合理的な境界条件を設 定しなければならないこと。

ところで, この種の解析は大規模な地すべり地塊の移 動現象を解析に反映しなければならないことや非線形性 の強い造波現象を取り扱うため，その解析領域は比較的 細かな要素分割を実施しなければならない。このため地 形変化の著しい局部域における造波の大きな変化を追跡 するためには，造波の時間追跡において陰的解法よりも 陽的解法が望ましいこと融から陽的解法で実施すること が多い。この場合に有限差分法では人工粘性係数 ${ }^{20)}$ や有 限要素法では質量行列の集中化に伴う解の減衰を押さえ るためランピングパラメータの導入22)が必要である。こ の值の設定は一般に経験的に決定されることが多く22), この設定值の如何によっては解析結果が相違することか ら慎重な設定が必要となっている。

このため有限要素法では移流項に起因する解の数值振 動による不安定性を低減させるため, 時間項に関して 2 次精度まで求めるBTD法 (Balancing Tensor Diffusivity）を適用した手法 ${ }^{233}$ や流速の上流側の節点により大き な重みを配慮し，有限差分法の風上化と同じ効果をもた らすぺトロフ・ガラーキン型の解析手法が, 安定化有限 要素法として提案されている ${ }^{25)}$ 。しかしながら, 前者の 手法は時間項を空間物理量で置き換え, 時間を 2 次精度 まで求める手法のため計算が煩雑であり ${ }^{23,24)}$ ，その簡略 化法や地すべり地塊の突入による造波現象の事例解析よ る解析精度の検討が残されている。

ここでは, 複雑な形状の領域を解析するため任意の要 素区分を行う非構造格子による解析が可能で, 計算機容
量の低減化が図られる陽的有限要素法による解析法を用 いる。この場合陽的有限要素法で一般に使用されている 人工粘性を制御するランピングパラメータの設定を必要 とせず，解の安定化のため時間項を 2 次精度まで考慮す るBTD法を簡略に適用する手法の提案を行うとともに， 浅水長波方程式を変形し, 地すべり地塊の突入による地 形变化量を解析式に直接導入する数值解析手法を提案す る。このことによって任意の速度，形状を有する地すべ り地塊の貯水池への突入による造波解析が可能となる。

第 1 節では，地すべりによる造波現象の災害事例と当 論文の目的を述べた。第 2 節では，地すべり地塊の貯水 池への突入を直接的に表現し, 数值計算の安定化のため に提案されているBTD法を組み込んだ基礎方程式つい て述べる。第 3 節ではそれの有限要素法による離散化手 法を述べる。第 4 節では造波の遡上解析において必要な 当論文で用いた移動境界条件の取り扱いについて述べる。 第 5 節では提案する解析手法を用いて移動境界問題とし ての段波解析, 地すべり地塊の貯水池内への側面からの 突入及び湖底隆起に伴う造波解析, 造波の斜面遡上解析 について数值実験を行い, 既往の種々の模型実験などと の比較を通して当手法の妥当性について述べる。

\section{2. 基礎方程式}

解析に用いる基礎方程式は, 三次元の非圧縮粘性流体 の基礎方程式を鉛直方向に平均化した浅水長波方程式で あり，平面二次元解析である。浅水長波方程式 ${ }^{23)}$,24 に拉 いて, 風力による自由水面のせん断応力, コリオリカ, 大気圧の不均等分布力を無視し, 水深 $h$ を水位標高 $\eta$ と 池底面の標高 $\eta_{b}$ の差 $h=\eta-\eta_{b}$ とすれば次式が得られる。 連続式

$$
\frac{\partial \eta}{\partial t}+\frac{\partial U}{\partial x}+\frac{\partial V}{\partial y}=\frac{\partial \eta_{b}}{\partial t}
$$

運動方程式

$\mathrm{x}$ 軸方向

$$
\begin{gathered}
\frac{\partial U}{\partial t}+\frac{\partial}{\partial x}(u U)+\frac{\partial}{\partial y}(v U)+g h \frac{\partial \eta}{\partial x}+\frac{1}{\rho} \tau_{x b} \\
-\left\{\frac{\partial}{\partial x}\left(\varepsilon \frac{\partial U}{\partial x}\right)+\frac{\partial}{\partial y}\left(\varepsilon \frac{\partial U}{\partial y}\right)\right\}=0 \cdots
\end{gathered}
$$

$\mathrm{y}$ 軸方向

$$
\begin{gathered}
\frac{\partial V}{\partial t}+\frac{\partial}{\partial x}(u V)+\frac{\partial}{\partial y}(v V)+g h \frac{\partial \eta}{\partial y}+\frac{1}{\rho} \tau_{y b} \\
-\left\{\frac{\partial}{\partial x}\left(\varepsilon \frac{\partial V}{\partial x}\right)+\frac{\partial}{\partial y}\left(\varepsilon \frac{\partial V}{\partial y}\right)\right\}=0 \cdots
\end{gathered}
$$

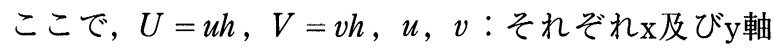
方向の流速成分, $h:$ 水深, $\rho:$ 水の密度, $\varepsilon:$ 水平渦動 粘性係数, $\tau_{x b}, \tau_{y b}$ : それぞれ底面のせん断応力の $\mathrm{x} 及 ひ ゙ \mathrm{y}$ 軸方向成分で, 抵抗則にマニング式を用いると次式で表 せる。 


$$
\begin{gathered}
\tau_{x b}=\rho g h \frac{n^{2} U \sqrt{U^{2}+V^{2}}}{h^{10 / 3}} \\
\tau_{y b}=\rho g h \frac{n^{2} V \sqrt{U^{2}+V^{2}}}{h^{10 / 3}}
\end{gathered}
$$

本解析では，(1)式の連続式を使用するため, 地すべり 地塊の貯水池への突入による池の底面形態の変化を時間 変化量として解析式に直接導入できることとなっている。 さて, (1)式の時間項についてテーラー展開を行い, 2 次精度まで求めると次式が得られる。

$$
\eta^{\Delta t}=\eta+\Delta t \frac{\partial \eta}{\partial t}+\frac{\Delta t^{2}}{2} \frac{\partial}{\partial t}\left(\frac{\partial \eta}{\partial t}\right)
$$

ここで上添え字 $\Delta t$ はタイムステップ後の值であるこ とを意味する。

(1)式に(5)式を導入すれば次式が得られる。

$$
\begin{aligned}
& \frac{\eta^{\Delta t}-\eta}{\Delta t}+\frac{\Delta t}{2} \frac{\partial}{\partial t}\left(\frac{\partial U}{\partial x}+\frac{\partial V}{\partial y}+\frac{\partial \eta_{b}}{\partial t}\right) \\
& +\frac{\partial U}{\partial x}+\frac{\partial V}{\partial y}=\frac{\partial \eta_{b}}{\partial t}
\end{aligned}
$$

ここで, 左辺の第 2 項の時間項に関して 2 次項を無視

し，整理を行うと次式が得られる。

$$
\begin{aligned}
& \frac{\eta^{\Delta t}-\eta}{\Delta t}+\frac{\Delta t}{2}\left\{\frac{\partial}{\partial x}\left(\frac{\partial U}{\partial t}\right)+\frac{\partial}{\partial y}\left(\frac{\partial V}{\partial t}\right)\right\} \\
& +\frac{\partial U}{\partial x}+\frac{\partial V}{\partial y}=\frac{\partial \eta_{b}}{\partial t} .
\end{aligned}
$$

ここで, Peraireら ${ }^{24)}$ は(7)式の左辺第 2 項を空間微分で 表しており，この手法がBTD法と呼ばれる ${ }^{25)}$ 。

この手法は後述する運動方程式にも適用されるが, 個々の解析要素の周辺積分を実施しなければならないな ど複雑な取り扱いが必要である ${ }^{23), 26)}$ 。このため $\partial U / \partial t$ と $\partial V / \partial t$ は個々の要素節点の時間変化量として表し, その まま離散化を行うこととした。このため複雑な周辺積分 を行わず簡単にBTD手法による安定化の効用を導入す ることができる。なお時間項の離散化は次式の中央差分 で実施することとした。

$$
\frac{\partial U}{\partial t}=\frac{U^{\Delta t}-U^{-\Delta t}}{2 \Delta t}
$$

同様の概念を適用して, $\mathrm{x}$ 軸方向の運動方程式にBTD 項を配慮した基礎方程式は次式で与えられる。

$$
\begin{aligned}
& \frac{U^{\Delta t}-U}{\Delta t}+\frac{\Delta t}{2} \frac{\partial}{\partial t}\left\{\frac{\partial}{\partial t}(u U)+\frac{\partial}{\partial y}(v U)+g h \frac{\partial \eta}{\partial x}\right\} \\
& +\frac{\partial}{\partial x}(u U)+\frac{\partial}{\partial y}(v U)+g h \frac{\partial \eta}{\partial x}+\frac{1}{\rho} \tau_{x b} \\
& -\left\{\frac{\partial}{\partial x}\left(\varepsilon \frac{\partial U}{\partial x}\right)+\frac{\partial}{\partial y}\left(\varepsilon \frac{\partial U}{\partial y}\right)\right\}=0
\end{aligned}
$$

ただし，拡散項は 2 次の微分項であり，底面抵抗項は 数値計算の不安定性に影響が少ないとして無視してい $ろ^{27)}$ 。ここでBTD項に関する項のみ移流速度及び水深值 を個々の要素の平均值（上添え字バー記号）として設定 すると簡略化できて次式が得られる。

$$
\begin{aligned}
& \frac{U^{\Delta t}-U}{\Delta t}+\frac{\Delta t}{2}\left\{\bar{u} \frac{\partial}{\partial x}\left(\frac{\partial U}{\partial t}\right)+\bar{v} \frac{\partial}{\partial y}\left(\frac{\partial U}{\partial t}\right)+g \bar{h} \frac{\partial}{\partial x}\left(\frac{\partial \eta}{\partial t}\right)\right\} \\
& +\frac{\partial}{\partial x}(u U)+\frac{\partial}{\partial y}(v U)+g h \frac{\partial \eta}{\partial x}+\frac{1}{\rho} \tau_{x b} \\
& -\left\{\frac{\partial}{\partial x}\left(\varepsilon \frac{\partial U}{\partial x}\right)+\frac{\partial}{\partial y}\left(\varepsilon \frac{\partial U}{\partial y}\right)\right\}=0 \cdots \cdots \cdots \cdots \cdots \cdots . . .(10)
\end{aligned}
$$

同様にしてy軸方向の運動方程式は次式で与えられる。

$$
\begin{aligned}
& \frac{V^{\Delta t}-V}{\Delta t}+\frac{\Delta t}{2}\left\{\bar{u} \frac{\partial}{\partial x}\left(\frac{\partial V}{\partial t}\right)+\bar{v} \frac{\partial}{\partial y}\left(\frac{\partial V}{\partial t}\right)+g \bar{h} \frac{\partial}{\partial y}\left(\frac{\partial \eta}{\partial t}\right)\right\} \\
& +\frac{\partial}{\partial x}(u V)+\frac{\partial}{\partial y}(v V)+g h \frac{\partial \eta}{\partial y}+\frac{1}{\rho} \tau_{y b} \\
& -\left\{\frac{\partial}{\partial x}\left(\varepsilon \frac{\partial V}{\partial x}\right)+\frac{\partial}{\partial y}\left(\varepsilon \frac{\partial V}{\partial y}\right)\right\}=0 \cdots \cdots \cdots \cdots \cdots \cdots . . .(11)
\end{aligned}
$$

(7)，(10)及び(11)式が本解析で使用する基礎方程式であり， 提案する手法をSBTD (Simple Balancing Tensor Diffusivity）と呼ぶことにする。

\section{3. 基礎方程式の離散化}

基礎方程式において時間方向の離散化はBTD法に よって害施されたので，重み関数と形状関数に同じ関数 を用いるパブノフ・ガラーキン法に従い空間方向に離散 化を行う。離散化において用いる要素の選択として, 流 速項は水位項よりも高次の補間を行う混合補間法が好ま しい結果を与えるとの報告もあるが27)，混合補間法を用 いた場合, すなわち, 移流速度項は線形補間, 水深項を 定数補間すると水深項は移流速度項の節点数に比較して より少ない節点数になる。当解析では移流速度 $u, v は$ 流束 $U, V$ を水深 $h$ で除して求めるため, この不足する 水深項の節点において補間関係より水深を内挿する必要 があり，この不足節点の水深量を他の節点より内挿補間 することは，薄層の流れがある境界領域では水深を支配 方程式の解として求めていないため精度の高い手法であ るとは言えない。そこで，ここでは流速と水深において 同じ節点数を用いる同時補間法を適用することとする。 いま重み関数として, $\eta^{*}, U^{*}, V^{*}$ を設定し, 重み付き 残差方程式をそれぞれ連続及び運動方程式について求め ると次式が得られる。

連続方程式

$$
\begin{gathered}
\iint_{\Omega} \eta^{*} \frac{\eta^{\Delta t}-\eta}{\Delta t} d \Omega+\frac{\Delta t}{2} \iint_{\Omega} \eta^{*}\left\{\frac{\partial}{\partial x}\left(\frac{\partial U}{\partial t}\right)+\frac{\partial}{\partial y}\left(\frac{\partial V}{\partial t}\right)\right\} d \Omega \\
+\iint_{\Omega} \eta^{*} \frac{\partial U}{\partial x} d \Omega+\iint_{\Omega} \eta^{*} \frac{\partial V}{\partial y} d \Omega=\iint_{\Omega} \eta^{*} \frac{\partial \eta_{b}}{\partial y} d \Omega \quad \cdots(12)
\end{gathered}
$$

運動方程式

$$
\begin{aligned}
& \iint_{\Omega} U \cdot \frac{U^{\Delta t}-U}{\Delta t} d \Omega \\
& +\frac{\Delta t}{2} \iint_{\Omega} U \cdot\left\{\bar{u} \frac{\partial}{\partial x}\left(\frac{\partial U}{\partial t}\right)+\bar{v} \frac{\partial}{\partial y}\left(\frac{\partial U}{\partial t}\right)+g \bar{h} \frac{\partial}{\partial x}\left(\frac{\partial \eta}{\partial t}\right)\right\} d \Omega \\
& \quad+\iint_{\Omega} U \cdot \frac{\partial}{\partial x}(u U) d \Omega+\iint_{\Omega} U \cdot \frac{\partial}{\partial y}(v U) d \Omega
\end{aligned}
$$




$$
\begin{aligned}
& +\iint_{\Omega} U^{*} g h \frac{\partial \eta}{\partial x} d \Omega+\iint_{\Omega} U^{*} \frac{1}{\rho} \tau_{x b} d \Omega \\
& -\iint_{\Omega} U \cdot\left\{\frac{\partial}{\partial x}\left(\varepsilon \frac{\partial U}{\partial x}\right)+\frac{\partial}{\partial y}\left(\varepsilon \frac{\partial U}{\partial y}\right)\right\} d \Omega=0
\end{aligned}
$$

ここで, $\Omega$ : 各三角形要素の面積領域

$$
\begin{aligned}
& \iint_{\Omega} V \cdot \frac{V^{\Delta t}-V}{\Delta t} d \Omega \\
& +\frac{\Delta t}{2} \iint_{\Omega} V^{*}\left\{\bar{u} \frac{\partial}{\partial x}\left(\frac{\partial V}{\partial t}\right)+\bar{v} \frac{\partial}{\partial y}\left(\frac{\partial V}{\partial t}\right)+g \bar{h} \frac{\partial}{\partial y}\left(\frac{\partial \eta}{\partial t}\right)\right\} d \Omega \\
& \quad+\iint_{\Omega} V \cdot \frac{\partial}{\partial x}(u V) d \Omega+\iint_{\Omega} V \cdot \frac{\partial}{\partial y}(v V) d \Omega \\
& \quad+\iint_{\Omega} V^{*} g h \frac{\partial \eta}{\partial x} d \Omega+\iint_{\Omega} V \cdot \frac{1}{\rho} \tau_{y b} d \Omega \\
& \quad-\iint_{\Omega} V^{*}\left\{\frac{\partial}{\partial x}\left(\varepsilon \frac{\partial V}{\partial x}\right)+\frac{\partial}{\partial y}\left(\varepsilon \frac{\partial V}{\partial y}\right)\right\} d \Omega=0 \quad \cdots . . . \cdots . . .(14)
\end{aligned}
$$

ここで領域を三角形要素で分割し，同時補間法として 未知諸量を一次要素で表すとすると重み関数は次式で表 される。

$$
\begin{aligned}
& \eta^{*}=\Phi_{\alpha} \eta^{*}{ }_{\alpha} \\
& U^{*}=\Phi_{\alpha} U^{*}{ }_{\alpha} \\
& V^{*}=\Phi_{\alpha} V^{*}{ }_{\alpha}
\end{aligned}
$$

ここで, $\Phi_{\alpha}$ : 形状関数, $\eta^{*}{ }_{\alpha}, U^{*}{ }_{\alpha}, V^{*}{ }_{\alpha}$ : 節点の重み

同様に空間物理量にも同じ形状関数を用いて，部分積 分を行い, 重み関数の任意性を考慮して離散化式を求め ると次式が得られる。

\section{連続方程式}

$$
\begin{gathered}
M_{\alpha \beta} \frac{\eta_{\beta}^{\Delta t}-\eta_{\beta}}{\Delta t}+\frac{\Delta t}{2} X_{\alpha \beta}\left(\frac{U_{\beta}^{\Delta t}-U_{\beta}^{-\Delta t}}{2 \Delta t}\right)+\frac{\Delta t}{2} Y_{\alpha \beta}\left(\frac{V_{\beta}^{\Delta t}-V_{\beta}^{-\Delta t}}{2 \Delta t}\right) \\
+X_{\alpha \beta} U_{\beta}+Y_{\alpha \beta} V_{\beta}=M_{\alpha \beta} \dot{\eta}_{\beta b} \ldots \ldots \ldots \ldots \ldots \ldots \ldots \ldots \ldots \ldots \ldots \ldots \ldots \ldots \ldots \ldots \ldots \ldots \ldots
\end{gathered}
$$

ここで上添え字・は時間微分を表す。

運動方程式

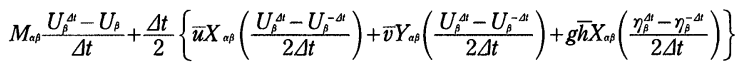

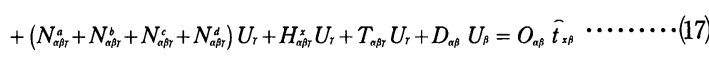

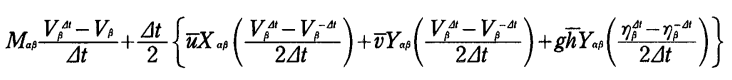

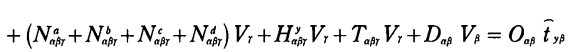
ここで,

$$
\begin{aligned}
& M_{\alpha \beta}=\iint_{\Omega} \Phi_{\alpha} \Phi_{\beta} d \Omega \\
& X_{\alpha \beta}=\iint_{\Omega} \Phi_{\alpha} \frac{\partial \Phi_{\beta}}{\partial x} d \Omega \\
& Y_{\alpha \beta}=\iint_{\Omega} \Phi_{\alpha} \frac{\partial \Phi_{\beta}}{\partial y} d \Omega \\
& N_{\alpha \beta \gamma}^{a}=\iint_{\Omega} \Phi_{\alpha} \Phi_{\beta} u_{\beta} \frac{\partial \Phi_{\gamma}}{\partial x} d \Omega \\
& N_{\alpha \beta \gamma}^{b}=\iint_{\Omega} \Phi_{\alpha} \frac{\partial \Phi_{\beta}}{\partial x} u_{\beta} \Phi_{\gamma} d \Omega
\end{aligned}
$$

$$
\begin{aligned}
& N_{\alpha \beta \gamma}^{c}=\iint_{\Omega} \Phi_{\alpha} \Phi_{\beta} v_{\beta} \frac{\partial \Phi_{r}}{\partial y} d \Omega \\
& N_{\alpha \beta r}^{d}=\iint_{\Omega} \Phi_{\alpha} \frac{\partial \Phi_{\beta}}{\partial y} v_{\beta} \Phi_{\gamma} d \Omega \\
& H_{\alpha \beta r}^{x}=g \iint_{\Omega} \Phi_{\alpha} \Phi_{\beta} h_{\beta} \frac{\partial \Phi_{r}}{\partial x} d \Omega \\
& H_{\alpha \beta r}^{y}=g \iint_{\Omega} \Phi_{\alpha} \Phi_{\beta} h_{\beta} \frac{\partial \Phi_{r}}{\partial y} d \Omega \\
& T_{\alpha \beta \gamma}=\frac{1}{\rho} \iint_{\Omega} \Phi_{\alpha} \Phi_{\beta} \tau_{b \beta} \Phi_{r} d \Omega \\
& O_{\alpha \beta}=\varepsilon \int_{s} \zeta_{a} \zeta_{\beta} d S \\
& D_{\alpha \beta}=\varepsilon \iint_{\Omega}\left(\frac{\partial \Phi_{\alpha}}{\partial x} \frac{\partial \Phi_{\beta}}{\partial x}+\frac{\partial \Phi_{\alpha}}{\partial y} \frac{\partial \Phi_{\beta}}{\partial y}\right) d \Omega \\
& \tau_{b}=\rho g h \frac{n^{2} \sqrt{U^{2}+V^{2}}}{h^{10 / 3}} \\
& \check{t}_{x}=\frac{\partial U}{\partial x} \cos \theta+\frac{\partial U}{\partial y} \sin \theta \\
& \check{t}_{y}=\frac{\partial V}{\partial x} \cos \theta+\frac{\partial V}{\partial y} \sin \theta
\end{aligned}
$$$$
\theta: \text { 境界に立てた法線方向と水平線とのなす角度 }
$$

ここで，(16)，(17)及び(18)式はタイムステップ後の単一の 未知量のみの記述式ではなく，タイムステップ後の流速 と水深を乗じた $U, V$ 及び水位標高 このままでは陽的に解くことができない。このため初回 はSBTD法を適用せず，未知諸量の初期值を求め, この 初期值を基に所要の誤差以内に収まるように繰り返し演 算によってタイムステップ後の未知諸量を求める。

この場合，繰り返し演算は，長周波成分による振動を 排除するため逆行列を求めず，質量行列 $M_{\alpha \beta}$ の集中化を 行わない整合質量行列で求めるマルチ・パス ${ }^{25)}$ を適用す る。この繰り返し演算の際にSBTD法における時間微分 項を(8)式で求めて, 繰り返し演算を行う。このアルゴリ ズムは以下の通りである。

いま，(16)式は整理を行うと次式で表現される。

$$
M \eta^{\Delta t}=-X\left(\frac{U^{\Delta t}-U^{-\Delta t}}{2 \Delta t}\right)-Y\left(\frac{V^{\Delta t}-V^{-\Delta t}}{2 \Delta t}\right)+f
$$

1 ）質量行列の集中化を実施した後，SBTD法を考慮せ ず水深りを次式より求める。

$$
\bar{M} \eta^{\Delta t}=f
$$

2 ）同様にして流速に関する未知諸量 $U, V$ を集中行列 化後にSBTD法を適用せず求める。以上の手法で求めら れた水深及び流速をマルチ・パス法の初期值とする。 3 ) (19)式を変換した次式で示すマルチ・パス法により, 整合質量行列によって未知諸量を求める。この際に SBTD法の時間項に関する計算值を求め，SBTD法によ る補正項として(21)式の右辺に導入する。これの繰り返し 演算を行い, 求められた未知諸量が許容の誤差の範囲内 に収まるまで行う。 


$$
\begin{aligned}
& \bar{M} \eta_{n+1}^{\Delta t}=-M \eta_{n}^{\Delta t}+\bar{M} \eta_{n}^{\Delta t} \\
& \quad-X\left(\frac{U_{n}^{\Delta t}-U^{-\Delta t}}{2 \Delta t}\right)-Y\left(\frac{V_{n}^{\Delta t}-V^{-\Delta t}}{2 \Delta t}\right)+f \cdots \cdots \cdots \cdots \cdot(21)
\end{aligned}
$$

ここで, $n$ は繰り返し演算回数を意味する。また, 上添 えマイナスの記号は行列の集中化を意味する。

以上の計算アルゴリズムによって, 時間精度を 2 次精 度まで高めたBTD法の適用が図られ, 解の減衰をもた らす行列の集中化を行わず整合質量行列による解が簡単 に求められる。

\section{4. 移動境界の取り扱い}

地すべり地塊の突入を起因とする造波は著しく高い波 高を有し，斜面上を高い標高域まで急激に遡上し，大規 模の被害をもたらす。この解析の初期においては，造波 の遡上域は水深がないわけであり，造波の遡上につれて 解析領域を拡大して取り込んでいく必要があり, その造 波の水深の先端線は移動境界となる。この移動境界を取 り扱う手法には, 解析領域の再分割を行うラグランジェ 的な移動境界法と解析領域の再分割を実施しないオイ ラー的な移動境界法に大別される ${ }^{28)}$ 。今回対象とする解 析条件は大幅な移動境界を有し, 解析領域も大幅に増減 する。この繰り返し計算の過程において要素網の再設定 を行うことは効率が悪く, 煩雑である。このため当解析 ではオイラー的な移動境界法を採用する。

オイラー的な移動境界の手法は, 個々の解析要素網の 水深の存在の有無を判定し, 全ての節点において水深が 許容値以下の場合は, 造波の遡上がないとして解析領域 の対象外とする。この手法は水深の存在する解析領域の みを対象とする効率的な解析法である ${ }^{29)}$ 。しかしながら， 個々の解析要素における水深の有無の判定において, ど れかの節点が水深の許容值以下の場合は水深が存在しな いことから, 流速を零として解析を進めると移流項の影 響で移動境界域の流速が急速に小さくなり, 造波の広が る速度が遅くなる。このためこの条件の節点では仮想流 速を与える手法が取られている ${ }^{27}$ 。

この仮想流域の取り方として松本ら ${ }^{27)}$ は 1 節点のみ水 深が許容值以下, すなわち, 水深のないドライベットの 場合のみに他の 2 節点の流速の平均值を仮想流速として 与えている。ここではSBDT法を採用する場合に平均流 速を用いていることから, 1節点のみ水深があり，他の節 点がドライベットの場合でもドライベットを含む要素の 中央地点における平均の流速值を求め, この值をドライ ベットの節点の仮想流速として与え, この境界条件で次 のタイムステップ時刻の未知諸量を求めることとした。

\section{5. 数値解析}

\section{1 段波解析}

前節で述べたSBTD法や移動境界の設定手法の精度を 検討するため, 図一 1 に示す長さ $10 \mathrm{~m}$ 水路における高 さ0. $2 \mathrm{~m}$ の水位差を有する段波の流れ解析を実施した。 なお中央部より右端部は流水の存在しないドライベット
として設定してある。解析条件は, 渦動粘性係数 $\varepsilon=0$, マニングの粗度係数 $n=0$ として検討を行う。ここで渦 動粘性係数及び粗度係数を零としたのは, 理論解との比 較を行うことと, 特に前者の項を零としたのはこの項を 考慮すると粘性の影響で数值計算は安定性が見られるの で粘性項を無視した厳しい条件下での数值計算の安定性 を検討するためである。また，時間増分幅 $\Delta t=0.001$ 秒， 要素分割幅は $0.2 \mathrm{~m}$ の均等分割, 水深の存在の有無を判定 する許容值は $0.001 \mathrm{~m}$ 設定し解析を行っている。当問 題において渦動粘性係数及び水路底面の摩擦を考えない 場合の粒速及び水深の理論解は次式で与えられている

$$
\begin{aligned}
& u(x ; t)=\frac{2}{3}\left(C_{0}+\frac{x}{t}\right) \\
& \eta(x ; t)=\frac{1}{9 g}\left(2 C_{0}-\frac{x}{t}\right)^{2} .
\end{aligned}
$$

ここで, $C_{0}$ は初期水深の波速であり, $C_{0}=\sqrt{g \eta_{0}}$ で求 められる。

解析モデルは図－10とおりである。水深及び流速の 解析結果を鉛直断面表示として図 - 2,3 に示す。平均 流速を用いたSBTD法は理論解との一致が非常によく, 特に流水の先端部おける流速が理論解の $2.8 \mathrm{~m} / \mathrm{sec}$ 近く まで追跡できており，提案された手法が妥当であること が理解できる。移流項の流速を平均流速を用いず，各節

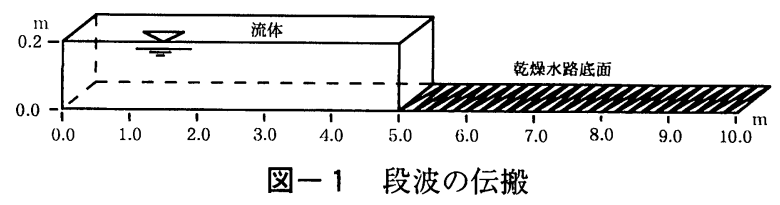

Fig. 1 Model of water dam breaking problem

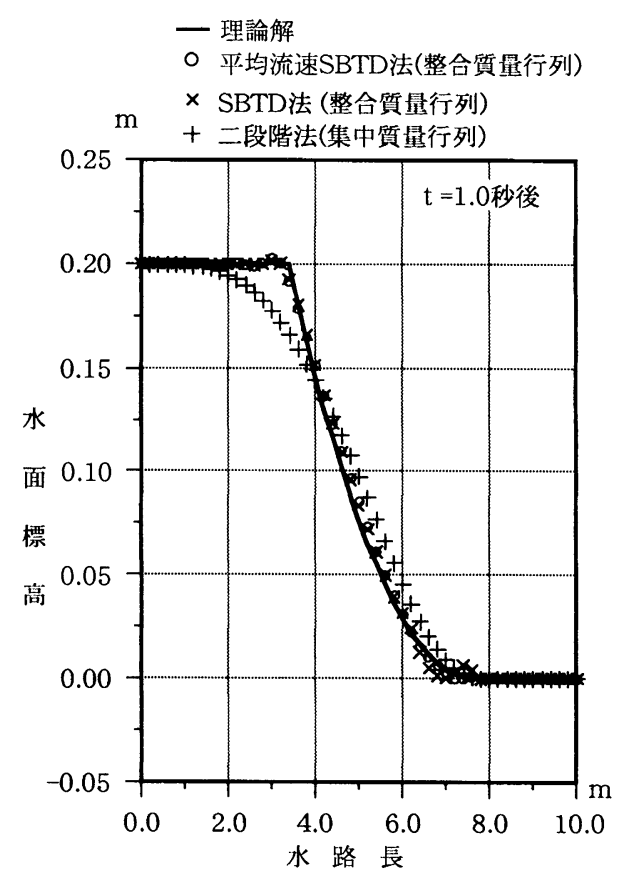

図一 2 段波の水面標高

Fig. 2 Water altitude of water dam breaking 
点の諸量としてより厳密な離散化を行った場合は，水深 に関する解析結果は先端部を除外して理論解との一致は 良いものの, 図-3の流速分布に見られるように，移動 境界域の段波の先端部では数值振動が見られている。こ れは移流項の流速 $u, v$ が解析結果から得られる流速に 水深を乗じた $U, V$ を水深 $h$ で除して求めるため, わず かな水深の数值振動によって影響を受けやすいことによ る。今回用いている移動境界手法が厳密に流水の連続性 を满足していないため, より厳密な離散化を行うSBTD 法を用いても数值振動を発生したことが原因であると考 えている。また，質量行列を集中化するため生じる人工 粘性を制御するためにランピングパラメータを $0.8 に$ 設 定し，解析を行った結果も併せて記載したが，まだ人工 粘性の影響が強く, 更なる検討が必要である。この種の 造波問題におけるランピングパラメータ值の設定法は未 だ確立されておらず，この人工粘性を制御するパラメー 夕を必要としない提案手法が精度の面に扔いて有利であ ると考えている。

\section{2 水路底面の隆起による津波解析}

今回提案する基礎方程式は流体の境界部の地形変化量 を直接取り込める手法である。この条件の導入精度を確 認するため図ー 4 示すように長さ $7.2 \mathrm{~m}$, 水深 $0.2 \mathrm{~m}$ の水 路底面が次式で表される隆起速度を有する長さ $2.44 \mathrm{~m} の$

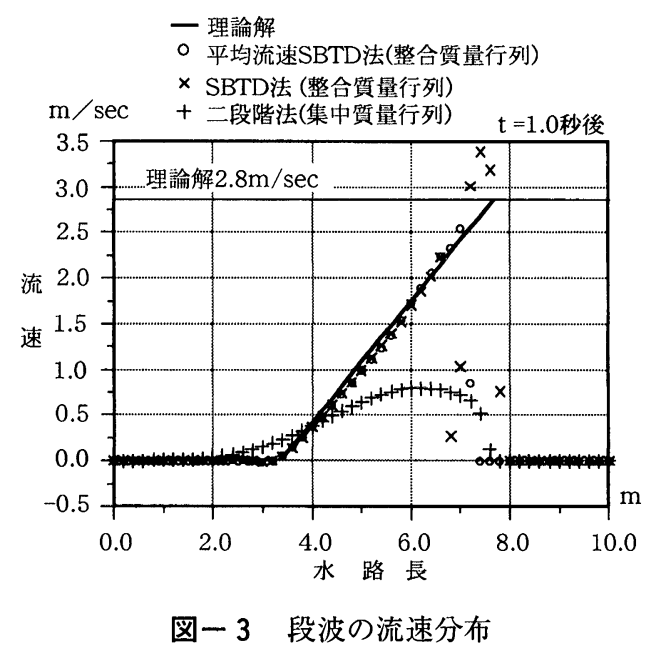

Fig. 3 Velocity distribution of water dam breaking

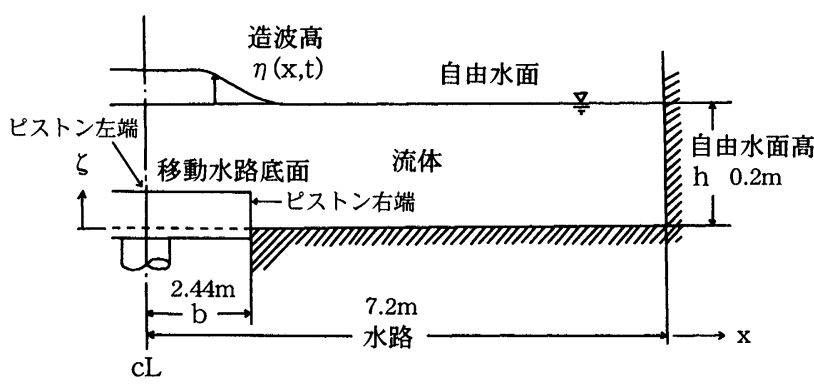

図ー4 二次元水槽と造波ピストン

Fig. 4 Two dimentional water tank and generation wave piston
ピストンによって形成された津波 ${ }^{30)}$ との比較解析を実施 した。このピストンの隆起速度は地すべり地塊の貯水池 への突入速度と比較して緩速なものと思われるが, 提案手 法と比較する現実斜面の実例が無いので, 本解析では模 型実験で使用されている次式のピストン速度を使用する。

$$
\zeta(t)=\zeta_{0}\left(1-e^{-\alpha t}\right)
$$

ここで, ：所要時刻におけるピストンの移動位置, $\zeta_{0}$ : 所要時刻におけるピストンの移動位置を制御するパ ラメータ

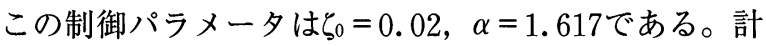
算条件として，5.1の段波解析と同じ目的により渦動粘 性係数 $\varepsilon=0$, マニングの粗度係数 $n=0$, 時間増分幅 $\Delta t$ $=0.01429$ (無次元表示), 要素の分割幅は $0.2 \mathrm{~m}$ の均等 分割を設定した。

図ー 5 はピストンの左端位置における水位標高の時間 変化を, 図ー6はピストン右端位置におけるそれを示し たものである。図ー 5 に扔ける水面変化量は模型実験結 果と非常によい一致を見ている。質量行列の集中化を 行っている解析は 2 段階ラックス・ウエンドルフ法によ る時間更新とランピングパラメータは 0.8 值を設定し ているが，まだ人工粘性の影響が強く，この值の検討が 必要であり,この検討を必要としない今回提案する SBTD法が有利であることが理解できる。図ー6では数 值計算の方が波高において模型実験より若干高く，波速 が遅くなっている。そこで今回提案する数值解析手法の 精度を検証すべく, 同じ解析条件で自由水面のエネル ギー式を用いた 2 次元断面に掞ける境界要素法 (BEM) による計算結果と比較したものを図ー 7 に示す。解析結 果は波高及び波速とも非常によい一致をみている。

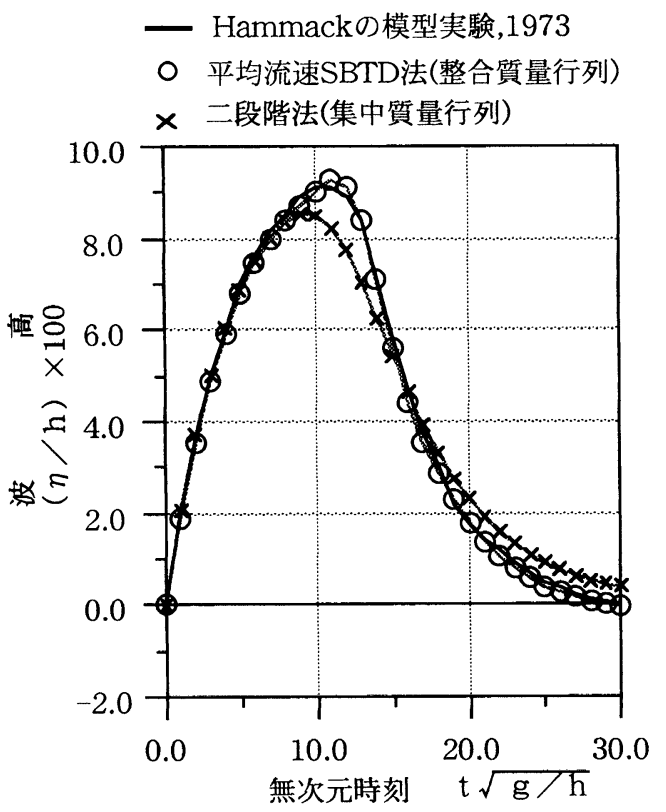

図－5 水路面の隆起による津波の波高（X=0.0）

Fig. 5 Tunami wave height generated by rising up of channel bottom $(X=0.0)$ 


\section{3 孤立波の鉛直壁面及び傾斜面の遡上解析}

地すべり地塊の貯水池への突入による造波は一種の孤 立波であるが，突入地塊の形状及び速度によって波形の 対称な孤立波は形成されず，その形状及び波高の予測は 困難である。ここでは今回提案する解析手法の精度を検 証するため理論解の得られている孤立波との比較を行う。

解析に用いる孤立波の水面標高は，次式に示される Laitoneによって得られている第 1 次近似の次式を用い た

$$
\eta=h+\operatorname{Asech}^{2}\left[\sqrt{\frac{3}{4} \frac{A}{h^{3}}}(x-c t)\right]
$$

ここで, $\eta$ : 孤立波の水面標高, $A$ : 初期波形の波高, $h:$ 水染, $g:$ 重力の加速度, $c=\sqrt{g h(1+A / h)}$

計算条件は渦動粘性係数 $\varepsilon=0$, マニングの粗度係数 $n$ $=0$ を設定し, 時間増分幅 $\Delta t=1.0^{-5}$ 秒, 初期水深 $1.0 \mathrm{~m}$, 水路長さ $12 \mathrm{~m}$ で要素分割幅は $0.4 \mathrm{~m}$ の均等分割を設定し た。当解析手法では解析領域の切り直しを実施しないた め, 孤立波の生成は(23)式で与えられる水深を左端の境界 条件として与えた。

波高比 $A / h=0.2,0.3$ の解析結果を図 $-8,9$ に示 す。解析結果は孤立波の進行とともに波高の減衰は見ら れず, 有限要素法で懸念される解のなまりは見られない。 しかし，理論值と比較して波高が若干低くなっており， 波高比が高くなるほどこの傾向が強く，波高比が 0.3 以

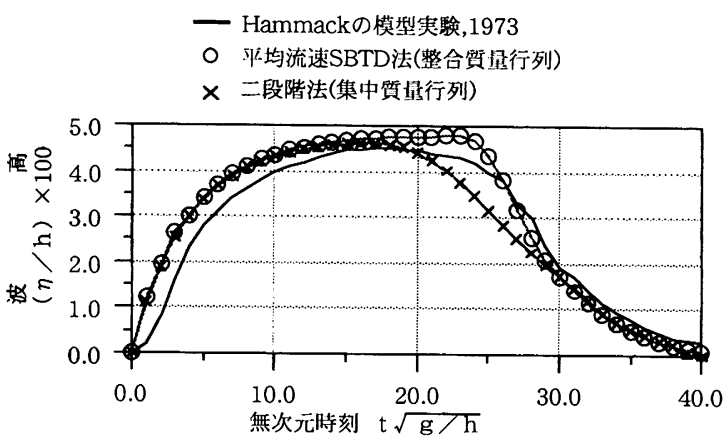

図－6 水路底面の隆起による津波の波高 $(\mathrm{X}=\mathrm{b})$

Fig. 6 Tunami wave height generated by rising up of channel bottom $(\mathrm{X}=\mathrm{b})$

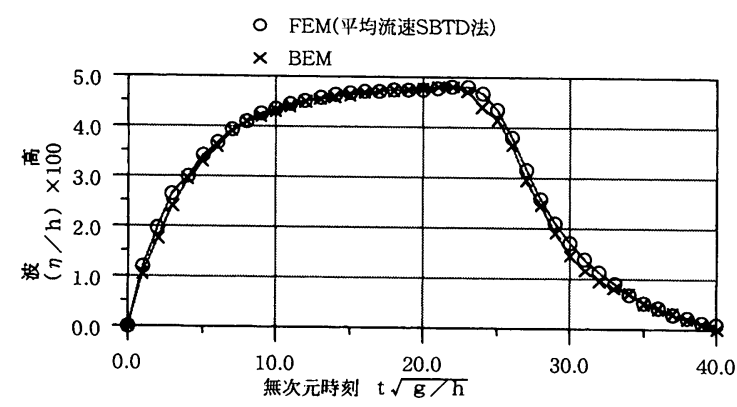

図一 7 提案手法と境界要素法 (BEM) による波高の比較

Fig. 7 Comparison of wave height between proposed method and BEM
上になると波形の時間変化量の追跡も孤立波の進行の先 端部で水面の振動が見られるようになる。これは鉛直方 向の流速が一定であると仮定する浅水長波式による解析 によることを起因としていると考えている。

図一10は鉛直壁面の孤立波の遡上高さを過去の事例解 析と比較して示す。解析結果は波高比 0.2 以下において は模型実験や理論解との一致はよいが，波高比が高くな ると鉛直方向に平均化した流速を用いる浅水長波式の影 響で低めの鉛直遡上高さが得られる。しかしながら，鉛 直壁面の衝突直前の孤立波の波高比を用いて解析を行う と理論解に近い結果が得られている。これ以上の波高比 の場合には鉛直方向の流速分布を評価した三次元解析が 必要であると考えている。

眓一 11 は傾斜角度 $30^{\circ}$ の傾斜面を遡上する孤立波 $(A / h=0.19)$ の解析結果を示す。最高遡上時の水位標 高が若干低めに計算されるもののその相違はわずかであ り，今回提案する移動境界の取り扱いが傾斜面上でも有 効であることが理解できる。

\section{4 土塊の貯水池への突入による造波解析}

当解析は図ー 12 に示すように傾斜上端面から移動地塊 が貯水池に突入した場合である。模型実験は道上ら ${ }^{22} に$ よって表ー1の条件で実施されている。
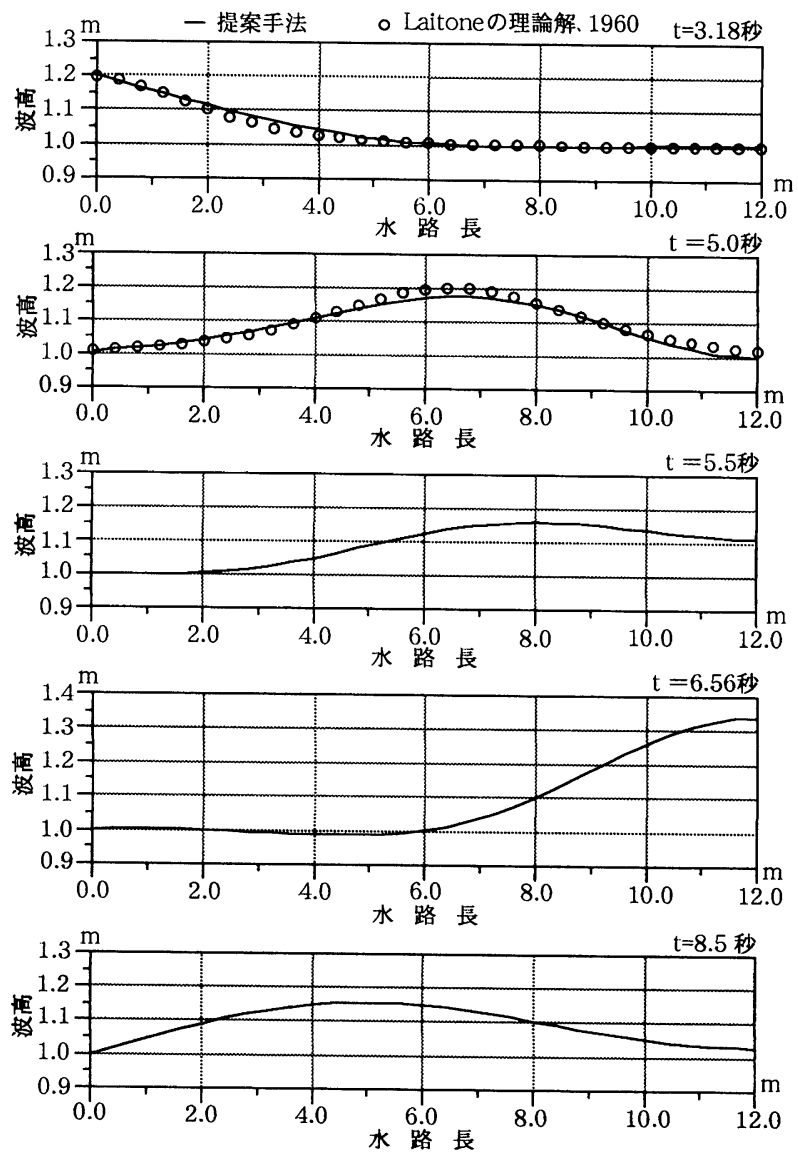

図一8 孤立波 $(\mathrm{A} / \mathrm{h}=0.2)$ の鉛直璧の反射

Fig. 8 Reflection of solitary wave with amplitude ratio $\mathrm{A} / \mathrm{h}=0.2$ on a vertical plane 

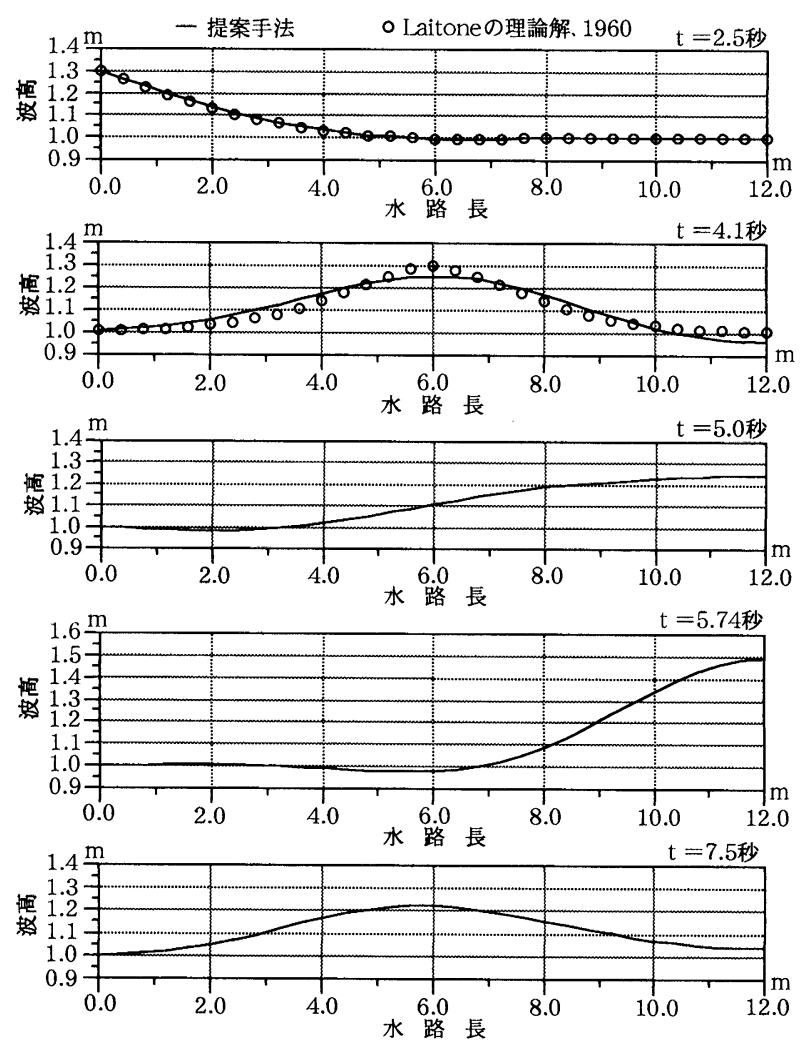

図一 9 孤立波（ $\mathrm{A} / \mathrm{h}=0.3 ）$ の鉛直譬の反射

Fig. 9 Reflection of solitary wave with amplitude ratio $\mathrm{A} / \mathrm{h}=0.3$ on a vertical plane

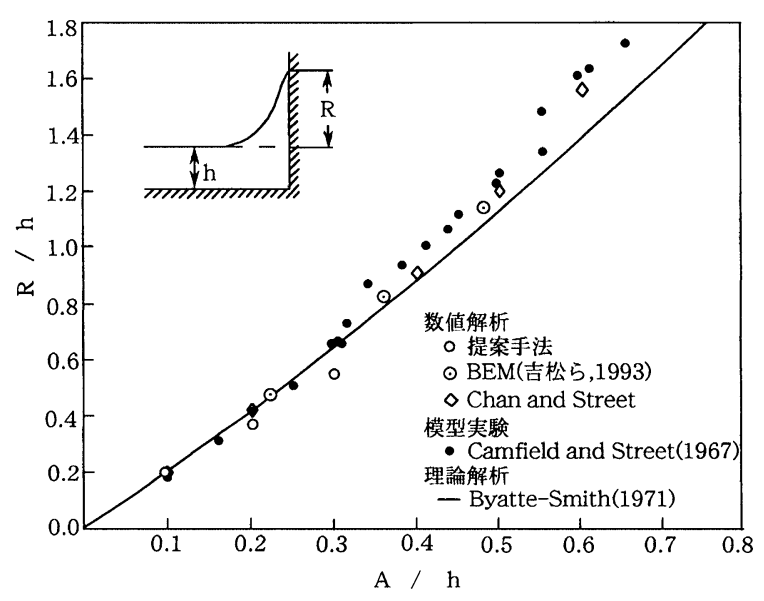

図一10 孤立波の鉛直璧面の遡上

Fig. 10 Reflection of solitary wave on a vertical plane

解析条件は，渦動粘性係数 $\varepsilon=0$, マニングの粗度係数 $n=0$ を設定し, 時間増分幅 $\Delta t=1.0^{-5}$ 秒, 要素の分割 幅は $0.1 \mathrm{~m}$ の均等分割である。流速と波高に関する解析 結果を図ー12に示すが，計算結果は模型実験に比較して 若干高めの値が得られているもののよい一致を見ている。 この高めの計算值が得られた原因として底面抵抗を無視 していることが原因であり，今回この仮定条件を考慮し ていない解析結果であることを勘案すると模型実験を再 現しているものと考えている。

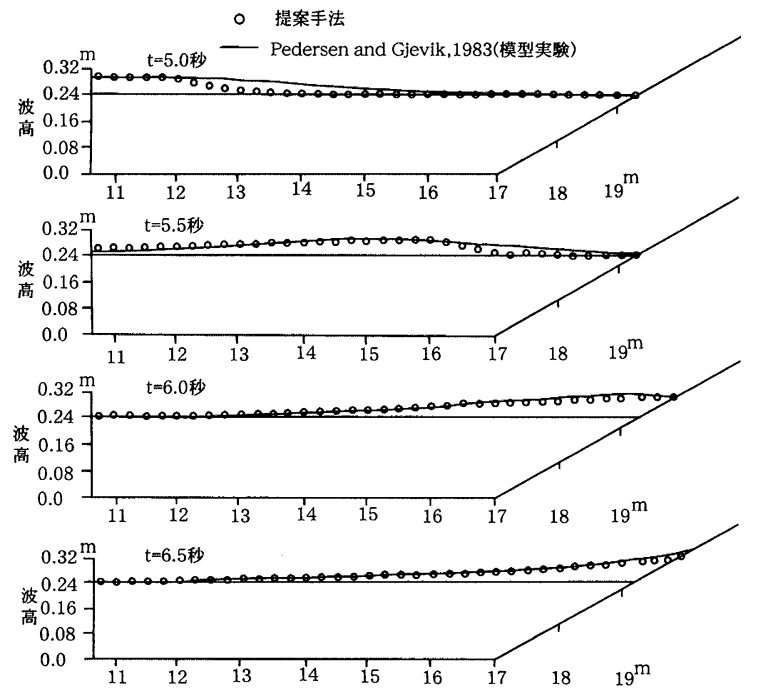

図一11 孤立波 $(\mathrm{A} / \mathrm{h}=0.19)$ の傾斜面 $\left(\theta=30^{\circ}\right)$ の遡上

Fig. 11 Run-up of solitary wave with amplitude ratio $\mathrm{A} / \mathrm{h}$ $=0.19$ on a plane inclined an angle $\theta=30^{\circ}$

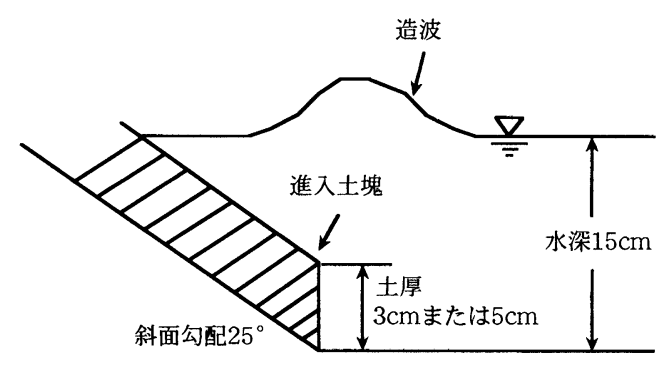

図ー12 土塊の進入モデル

Fig. 12 Model of inflow earth mass

\section{6. あとがき}

地すべり地塊の貯水池への突入に起因する造波の予測 に関する数值解析手法を検討した。解析に用いた手法は, 複雑な地形形状と地すべり地塊の貯水池の突入条件を容 易に勘案できる非構造格子の要素区分を行う有限要素法 であるが，安定化のためのBTD項を取り込んだ解析手 法を検討した。得られた結論は以下の通りである。

1）地すべり地塊の貯水池への突入の条件を直接考慮す る基礎方程式を導出した。

2 ）有限要素法の解析において, 整合質量行列を用いた 計算において数值不安定性を低減するためBTD項 を簡単に勘案する手法を提案した。

3 ) 既往の模型実験結果と整合質量行列を用いた解析手 法の計算結果との比較を行い, 提案手法の妥当性を 確認した。

有限要素法の数值安定性を確保するためBTD項を導 入し，質量行列の集中化を行わない整合質量行列を用い た解析手法を検討したが，BTD項の問題点として安定 性限界が低く ${ }^{33}$ ，比較的小さな夕イムステップ值を採用 しなければならない。また，マルチ・パス法における繰 り返し計算回数が $5 \sim 6$ 回に達するなど計算効率の改善 の必要がある。このため数値計算のより安定化と計算時 


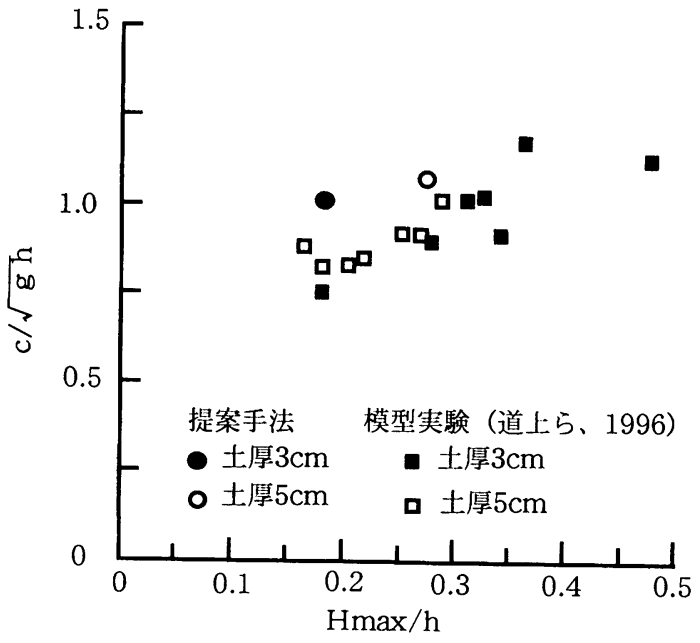

図一13 水路へ突入した土砂塊による造波

Fig. 13 Water waves generated by inflow earth mass to water channel

\section{表－1 模型実験の条件（実験B，道上ら, 1996）}

Table 1 Condition of Model Experiment

\begin{tabular}{|c|c|c|c|c|c|}
\hline 実験No & $\begin{array}{c}\text { 斜面勾配 } \\
\left({ }^{\circ}\right)\end{array}$ & $\begin{array}{c}\text { 水深 } \\
(\mathrm{m})\end{array}$ & $\begin{array}{c}\text { 土厚 } \\
(\mathrm{m})\end{array}$ & $\begin{array}{c}\text { 土砂流入速度 } \\
(\mathrm{m} / \mathrm{sec})\end{array}$ & $\begin{array}{c}\text { 土砂移動距離 } \\
(\mathrm{m})\end{array}$ \\
\hline 1 & 25 & 0.15 & 0.03 & 0.535 & 0.3547 \\
\hline 2 & 25 & 0.15 & 0.05 & 0.558 & 0.3547 \\
\hline
\end{tabular}

間の短縮のための上流化法などの安定化項の検討や提案 手法の現実地すべりを起因とする造波の解析への適用に ついて三次元領域における要素サイズの影響, 地すべり 地塊と流体との相互作用機構および現地適用に関する CFL条件 $\left.(\Delta t \leq \Delta x / \sqrt{g h})^{25}\right)$ についての検討が今後残さ れた課題である。

\section{参考文献}

1) Jorstad F. A.(1968): Waves Generated by Landslides in Norwegian Fjord and Lakes, Publication 79, Norwegian Geotechnical Institute, Oslo, Norway, pp. 13-31

2) 相田 勇 (1982)：山崩れによる津波, 海洋科学, Vol. 9, pp. 31 $-38$

3 ) Davidson, D. D. and McCartney, B. L.(1975) : Water Waves Generated by Landslides in Reservoir, Proc. of ASCE, Vol. 101, No. HY12, pp. 1489 - 1501

4 ) Slingerland, R. L. and Voight, B. (1979) : Occurrence, Properties, and Prediction Models of Landslide Generated Water Waves, Rockslides and Avalanches, Vol.2, Elsevier Science Publication, pp. $317-397$

5 ) Clifford, A. P. and Harris, D. V. (1982): Prediction of Landslide-Generated Water Waves, Comission International, Des Grands Barrages, Riode Janeiro, pp. 283-316

$6)$ Kiersch, G.(1964) : Vaiont Reservoir Disaster, Civil Engineering, ASCE, No. 34 , pp. $32-47$

7 ) Muller, P.(1964) : The Rock Slide in the Vajont Valley, Jour. of the Inter. Society of Rock Mechnics, Vol. 2, pp. 148-212

$8)$ Lane, K. S.(1966) : Stability of Resorvoir Slopes, Proc. of Symposium on Rock Mechanics, Minneapolis, Minnesota, pp. $321-336$

9 ) Miller, D. (1966) : Giant Waves in Lituya Bay, Alaska, U. S.
Geological Servey, Professional, Paper, 354-C, pp. 51-83

10）三好 寿(1977)：津波,イルカブックス海洋出版, No. 12, p. 30

11) Noda, E. K.(1970) : Water Waves Generated by Landlsides, Proc. of ASCE, Vol. 96, No.WW4, pp. 835-855

12) Wiegel, R. L., Noda, E. K., Kuba, E. M., Gee, D. M. and Tornberg (1970) : Water Waves Generated by Landslides in Reservoirs, Proc. of ASCE, Vol. 96, No.WW2, pp. 307-331

13) Davidson, D. D. and Whalin, R. W., (1974) : Potential Landslide-Generated Water Waves, Libby Dam and Lake Koocanusa, Montana, U. S. Army Engineering Waterways Experiment Station, Technical Report, p. 30

14) Pedersen, G. and Gjevik, B.(1983) : Run-Up of SolitaryWaves, Jour. of Fluid Mechanics, Vol. 135, pp. 283-299

15) Heinrich, P.(1992) : Nonlinear Water Waves Generated by Submarine and Aerial Landslide, Jour. of Waterway, Port, Coastal and Ocean Engineering, Vol.118, No. 3, pp. 249-266

16) Raney, D. C. and Butler, H. L.(1975) : A Numerical Model for Predicting the Effect of Landslide Generated Water Waves, U. S. Army Engineering Waterways Experiment Station, $\mathrm{H}-75-1$, p. 25

17) Raney, D. C. and Butler, H. L.(1976) : Landslide Generated Water Wave Model, Proc. of ASCE, Vol. 102, No.HY9, pp. $1269-1282$

18）村上泰啓，中村興一，清水康行, 1991 ：貯水池に扔ける表面波 伝播シミュレーション, 土木学会第46回年次学術講演会, pp. $466-467$

19) Harbitz, C. B., Pedersen, G. and Gjevik, B.(1993) : Numerical Simulations of Large Water Waves due to Landslides, A. S. C. E., Jour. of HE., Vol. 119, No. 12, pp. 1325-1342

20）道上正視（1995）：眝水池内での大規模崩壊に伴う水位変動に ついて, ダム技術, No. 105, pp. 4-11

21) Koutitas, C. G.(1977) : Finite Element Approach to Waves due to Landslides, Proc. of ASCE, Vol. 103, No.HY9, pp. 1021 $-1029$

22）小林紘士，和田 明，角湯正剛（1989）：流体数值実験，朝倉 書店, p. 159

23）二之宮弘, 大西和榮, 小林錦子, 大浦洋子（1997）：パソコン による水環境流れ解析, 朝倉書店, p. 244

24) Peraire, J., Zienkiewicz, O. C. and Morgan, M.(1986) : Shallow Water Problems: A General Explicit Formulation, Inter. Jour. for Numer. Methods in Eng., Vol. 22, pp. 547-574

25）川原睦人, 野村卓史, 樫山和男, 奥田洋司（1988）：有限要素 法による流れのシミュレーション，日本数值流体力学会有限 要素法研究委員会, シュプリンガー・フェアラーク東京, p. 298

26) Otane, E. (2000) : A Stabilized Finite Element Method for Imcompressible Viscous Flow using A Finite Increment Calculas Formulation, Comput. Methods. Appl. Mech. Engrg. Vol. 182, pp. 355-370

27）松本純一，梅津 剛，川原睦人（1998）：除的有限要素法によ る浅水長波流れと河床変動解析, 応用力学論文集, Vol. 1, pp. $263-272$

28）川原睦人 (1996)：移動境界流れ解析, 東京大学出版会, p. 184

29) Kawahara, M. and Umetu, T.(1986) : Finite Element Method for Moving Boundary Problems in River Flow, Inter. Jour. for Numer. Methods in Eng., Vol. 6, pp365-386

30) Hammack, J. L., 1973 : A Note on Tunami : Their Generarion and Propagation in An Ocean of Uniform Depth, Jour. of Fluid Mech., Vol. 60, Part4, pp. $769-799$

31) Laitone, E. V., 1960: The Second Approximation to Cnoidal and Solitary Waves, Jour. of Fluid Mech., Vol. 9, pp. 440-444

32）道上正視，檜谷 治，木戸正二（1996）：貯水池内での土砂流 入に伴う水面波に関する実験的研究，鳥取大学工学部研究報 告, Vol. 27, No. 1, pp. 105-112

33）丸岡 晃，太田真二，平野廣和，川原睦人 (1997)：同次補間 を用いた陰的有限要素法による非圧縮粘性流れの解析, 構造 工学論文集, Vol. 43A, pp. 383-394

（原稿受付2001年 1 月 12 日，原稿受理2001年 7 月 6 日） 